doi 10.18524/2077-1746.2021.2(49).246891

УДК 581.9 (477.74)

O. Yu. Bondarenko, Ph.D., assistant professor

S. L. Myronov, student

Odesa National Mechnykov University, Faculty of Biology,

Department of Botany

2, Dvoryanska str., Odesa 65082, Ukraine,

\title{
EUPHOR\%IA DAVIDII SUBILS (EUPHORBIACEAE) IN FLORA OF RAILWAY TRACKS OF DNIESTER BAY BAR
}

On the Dniester embankment, between station Karolina-Buhas and Sonyachna, in the space between the tracks, as well as near these tracks, on the substrate of gravel, seven localities or the synanthropic species on $E$. davidii were recorded. In general, the examples found on the south slopes of railway tracks (compared to the north ones) are worse developed, are less branch out and are mainly represented by a smaller number of generative individuals.

Key words: Euphorbia davidii; railway tracks; Dniester bay bar

The flora of the south of Ukraine is notable for its significant transformation and, as a consequence, for its considerable number of synanthropic species, including invasive ones $[1,2,3,8,11,12]$. The presence and expansion of anthropogenically transformed areas, as well as the existent level of permanent influence of human activity, probably, will contribute to it in the future too.

The issues, related to distinction and identification plants the species in the territory of North and South America, as well as problems designation invasive exemplars in flora of European countries and North Caucasus (Abkhazia, Ossetia), are covered in modern scientific literature, in particular in Ukrainian literature [5, 9, 10, 21]. It is noticed that the species expands its distribution area at a rapid rate $[4,22]$. The study of the chemical composition of E. davidii plants is considered [19].

Euphorbia davidii (tetraploid, $2 \mathrm{n}=56$ ) originates from North America (the north of Mexico, the USA, Canada), it was distributed in Europe (Bulgaria, Moldova, Russia, Ukraine), according to certain assumptions, with exported grain. The localities of the species are also registered in South America (Argentina), Australia, Asia [4, 13, 15, 16, 17, 18, 20]. For the year 2013, in Europe there were known 46 localities in ten European countries [22].

In Ukraine, there are noticed localities in Odessa, Amvrosiivka, Donetsk, Chop, Mukachevo, Kyiv, Kherson, Zatoka, etc. For the majority of these locations is pointed out that plants of this species were registered on railway tracks or nearby [22].

Plants E. davidii are represented at the picture (fig. 1,2). 


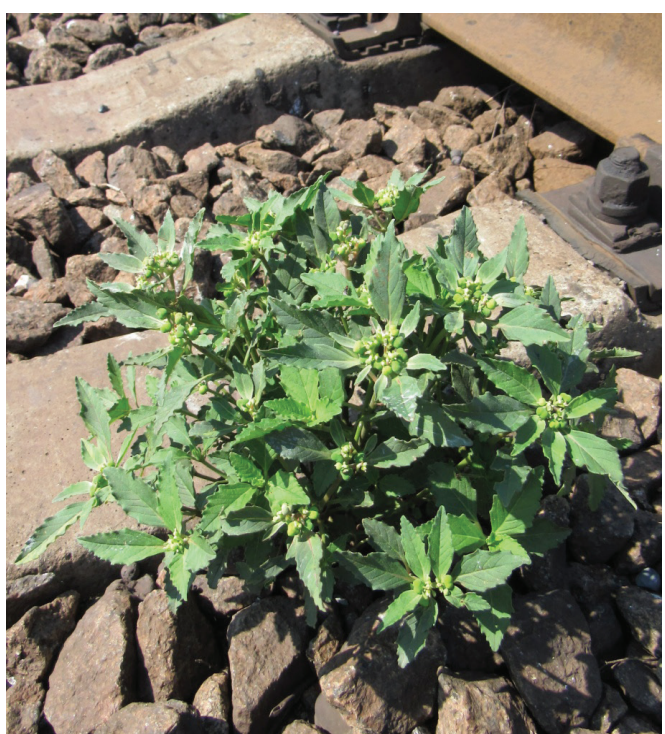

Fig. 1. Euphorbia davidii. Habitus. Photo by Bondarenko O. 11 August, 2021, near the railway stop Morska

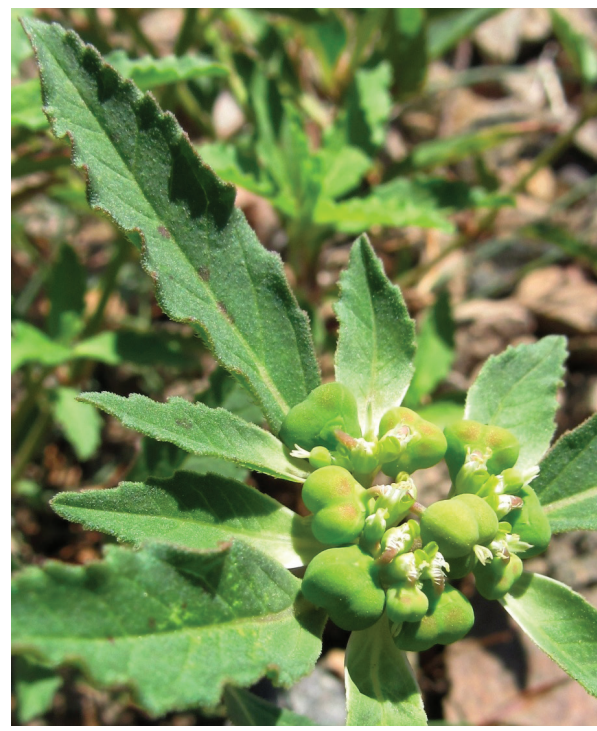

Fig. 2. Euphorbia davidii. A part of an inflorescence. Photo by Bondarenko $O$. 8 August, 2021, near the railway stop Limanska

Euphorbia davidii subsp. Poinsettia - plants are tomentose, from the basis or from the middle are very branchy. Leaves are oblong and serrate. Seeds are 2,4-2,9 $\mathrm{mm}$ in length, in transection are tetrahedral. On the surface of seeds there are few big enough irregularly-shaped tubercles or flanges [12]. It is an annual plant, up to $40 \mathrm{~cm}$ high, blooms in august.

The species is an invasive plant, neophyte, in the territory of Ukraine is represented mainly in anthropogenically transformed sectors of seaports, railway tracks, abandoned lands $[6,22]$.

In order to study the flora of anthropogenically transformed areas of the Dniester embankment, using the pathway method, studied railway tracks and adjacent areas between railway stations Karolina-Bugas and Sonyachna. Statistical separate measurements were performed. Railway tracks are directed from east to west. The nearest locality of $E$. davidii, according to literature, is situated on railway tracks of the railway station Zatoka (also related to Dniester bay bar, in the direction of Bilhorod-Dnistrovskyi) [22]. In accordance with oral report of Ph.D., assistant professor Vasiljeva T. and Ph.D., assistant professor Kovalenko S., they also found $E$. davidii on Dniester bay bar.

For other natural or anthropogenically transformed ecotopes og the Dniester overflow of E. davidii plants we have not revealed.

In pursuant to geobotanical subdivision of Ukraine, the area is integrated in geobotanical district of cereal and wormwood-cereal steppe of Odessa, saline meadows, 
solonchaks and vegetation of carbonate outcrops, Black Sea-Azov steppe subprovince, Pontic steppe province and Eurasian steppe region [7].

The locations being examined are completely transformed by an anthropogenic factor and represented by a crushed stone substratum with concomitant contamination, which is specific for rail transport. There are observable some evidence of restoration (adding) of substratum, in consequence of which one of the previously noticed localities (from July 2021) was not found. In addition, in some places there are notable evidence of mowing vegetation on the crushed stone railroad embankment.

Railway tracks are frequently a place of detection of synanthropic species, including invasive ones [14].

The detected localities have the following coordinates:

$46^{\circ} 07^{\prime} 51.8^{\prime \prime} \mathrm{N}, 30^{\circ} 30^{\prime} 51.9^{\prime \prime} \mathrm{E}$. There are present about 400 individuals up to 15 $\mathrm{cm}$ high; most of them (>250) are registered on the south side of the railroad embankment. On the north side there are situated about 80 examples. Specifically in-between of rails there are about to 15 individuals, but exactly here the plants are better developed, branch well, possess bigger leaves and higher number of inflorescences. As of 23 August 2021, more than $70 \%$ of plants have developed seeds. The locality is up to 20 meters in length. About 10 exemplars of plants were found beyond the railways, on the sandy substratum from the south side. They possess, in most cases, just one stem, insignificant branching, are fruitful.

$46^{\circ} 07^{\prime} 42.1^{\prime \prime} \mathrm{N}, 30^{\circ} 30^{\prime} 42.9^{\prime \prime} \mathrm{E}$. Specifically in-between of rails there are registered 11 exemplars, up to $15 \mathrm{~cm}$ high. Only two plants have developed seeds. Two more were found on the north side of the railroad embankment. The locality is 2 meters long. As of 23 August 2021, the major part of plants possessed generative organs. Beyond the ecotope of railway tracks the exemplars of $E$. davidii were not found.

$46^{\circ} 07^{\prime} 03.3^{\prime \prime} \mathrm{N}, 30^{\circ} 30^{\prime} 22.3^{\prime \prime} \mathrm{E}$. The solitary exemplars with a total number of 32 are situated in the locality, which length is 30 meters, mostly in-between of the rails. The plants, with a few minor exceptions, are poorly developed, they are up to $13 \mathrm{~cm}$ high. As of 23 August 2021, seven generative individuals were found, up to $10 \mathrm{~cm}$ high. Beyond the ecotope of railway tracks no exemplars were found.

$46^{\circ} 06^{\prime} 32.9^{\prime \prime} \mathrm{N}, 30^{\circ} 30^{\prime} 08^{\prime \prime} \mathrm{E}$. There are more than 500 exemplars in the locality that is up to 20 meters long, among them: in interrail space - only 47 plants, on the north side of the railroad embankment - 27 plants. As of 23 August 2021, on the south side of the embankment only about $50 \%$ (by sight) of plants were fruiting. On the north side the majority (by sight - up to $80 \%$ ) of plants have developed seeds. Beyond the ecotope of railway tracks no exemplars were found.

$46^{\circ} 05^{\prime} 59.8^{\prime \prime} \mathrm{N}, 30^{\circ} 29^{\prime} 31.6^{\prime \prime} \mathrm{E}$. In interrail space 57 exemplars were distinguished, twelve more - on the south side of the railway embankment, on the north side - 2 individuals. The plants are comparably well-developed; as of 23 August 2021, most of plants were ramiform and have developed fruits. Beyond the ecotope of railway tracks no exemplars were found. 
$46^{\circ} 05^{\prime} 35.6^{\prime \prime} \mathrm{N}, 30^{\circ} 29^{\prime} 07.3^{\prime \prime} \mathrm{E}$. The locality (more than 50 meters in length) is represented by a considerable number of exemplars: over 2000 plants are situated on the both slopes of the crushed stone embankment. The plants are lowly, up to 10-12 $\mathrm{cm}$ high. The individuals from the south side of the embankment, in comparison with exemplars from the north side, are poorly ramiform. A minor part of the exemplars is situated beyond the railway tracks, on the sandy substratum of the bay bar. In interrail space only 75 individuals were distinguished, among them, 68 plants (as of 30 August 2021) have developed fruits.

$46^{\circ} 05^{\prime} 00.8^{\prime \prime} \mathrm{N}, 30^{\circ} 28^{\prime} 34.8^{\prime \prime} \mathrm{E}$. This locality is up to 50 meters long, the individuals of Euphorbia davidii were registered only on slopes of the crushed stone embankment, in interrail space there were not noticed any of E.davidii exemplars. The number of individuals - more than 300, particular plants reach the size about $20 \mathrm{~cm}$. Most of plants are low-growing, poorly ramiform, but up to $80 \%$ (by sight) of them, as of 30 August 2021, have developed fruits. Beyond the railways no exemplars were found.

\section{Conclusions}

1. In 2021, when studying the flora of anthropogenically transformed ecotopes, on the sections of railway tracks up to eight kilometers long, 7 habitats of E. davidii were found between the stations Karolina-Buhas and Sonyachna. The concentration of plants in the localities ranges from 32 species to about 2000.

2. Plants in the space between the tracks, compared with gravel slopes, few.

3. The number a plants on the southern side of the slopes of the tracks is greater. However, compared to the northern slopes, they are less branched and, as of the time of the research, are represented by fewer generative individuals.

Стаття надійшла до редакції 14.10.2021

\section{Список використаної літератури}

1. Бондаренко О.Ю. Конспект флори пониззя межиріччя Дністер - Тилігул / О. Ю. Бондаренко.- Київ: Фітосоціоцентр, 2009.- 332 с.

2. Бондаренко О.Ю. Флора пониззя межиріччя Дністер - Тилігул: дис. канд. біол. наук спец. 03.00.05 / О.Ю. Бондаренко.- Київ, 2015.- 380 с.

3. Васильєва, Т.В. Конспект флори Південної Бесарабії. Одеський національний університет ім. І. І. Мечникова, Одеса, 2003.- С. 1-250.

4. Гельтман Д. В. Американский вид Euphorbia davidii Subils (Euphorbiaceae) во флоре Восточной Европы и Северного Кавказа / Д. В. Гельтман // Turczaninowia. - 2012.- Т. 15, № 1.- С. 37-39.

5. Гузік Я. Нові локалітети карантинного бур'яну Euphorbia dentata Michx. в Україні / Я. Гузік, В. В. Протопопова, О. О. Кагало, І. І. Мойсеєнко, Б. Г. Проць, М. В. Шевера // Укр. бот. журн. - 1997.- Т. 54, № 3.C. $280-283$.

6. Двірна Т.С. Знахідки Euphorbia davidii Subils (Euphorbiaceae) на території Лівобережного Лісостепу України / Т. С. Двірна, К. О. Звягінцева // Укр. ботан. журн. - 2013. - Т. 70, № 3.- С. 351-353.

7. Дідух Я. П. Геоботанічне районування України та суміжних територій / Я. П. Дідух, Ю. Р. Шеляг-Сосонко // Укр. ботан. журн.- 2003.- Т. 60, № 1.- С. 6-17.

8. Інвазійні види у флорі Північного Причорномор'я / [В. В. Протопопова, М. В. Шевера, С. Л. Мосякін та ін.].- К.: Фітосоціоцентр, 2009.- 56 с.

9. Коваленко С.Г. Нові види синантропної флори м. Одеси та причорноморських портів / С.Г. Коваленко, С.П. Петрик, І.П. Ружицька, Т. В. Васильєва-Немерцалова // Укр. бот. журн. - 1993.- Т. 50, № 1.- С. 114-117. 
10. Коваленко С.Г. Новые находки Euphorbia dentata в Причерноморье / С. Г. Коваленко, И. П. Ружицкая, С. П. Петрик // Бюлл. Главн. бот. сада.-1992.- Вып. 163.- С. 62.

11. Протопопова В.В. Синантропная флора Украины и пути её развития / В.В. Протопопова.- К.: Наук. думка, 1991.- 192 с.

12. Протопопова В. В. Інвазійні види у флорі України. І. Група високо активних видів / В. В. Протопопова, М. В. Шевера // GEO\&BIO.- 2019.- Vol. 17.-116-135.

13. Тохтарь В. К. Euphorbia davidii Subils (Euphorbiaceae) - новый вид для Центрального Черноземья (Россия) / В. К. Тохтарь, А. Ю. Курской // Фиторазнообразие Восточной Европы, 2019.- Т. ХІІІ, № 4.- С. $397-$ 401. doi: 10.24411/2072-8816-2019-10058

14. Burda R.I. Invasion, distribution and naturalization of plants along railroads of the Ukrainian south-east / R. I. Burda, V. K. Tokhtar // Укр. ботан. журн.- 1992.- T. 49, № 5.- C. 14-18.

15. Marchessi J.E. Presencia de Euphorbia davidii Subils (Euphorbiaceae) en la Provincia de Buenos Aires: morfología y anatomía de la especie / J. E. Marchessi, R. Subilis, R. L. Scaramuzzino, H. N. Crosta, M. F. Eseiza, H. M. Saint Andre, V. F. Juan // Kurtziana. - 2011. - 36 (1).- pp. 45-53.

16. Oprea A. Euphorbia davidii Subilis (Euphorbiaceae) - an alien species new to the Romanian flora / A. Oprea, Z. Barina, C. Sîrbu // Contribuții Botanice. - 2012.-48.- pp. 7-12.

17. Pinke G. The first occurrence of Euphorbia davidii in Hungary / G. Pinke, S. Molnar, V. Garamvölgyi, Z. Barina // Nöwenyvedelem. - 2012.- 48 (3).- pp. 117-120.

18. Purger D. Euphorbia davidii Subils (Euphorbiaceae), a new alien species in the flora of Serbia / D. Purger, D. Vajgand, N. Mićić, K. Vajgand // Botanica Serbica. - 2015.-39 (1).- pp. 49-52.

19. Rédei Dóra. First phytochemical investigation of secondary metabolites of Euphorbia davidii Subils. and antiproliferative activity of its extracts / Dóra Rédei, Norbert Kúsz, Máté Szabó, Gyula Pinke, István Zupkó, Judit Hohmann1 //Acta Biologica Hungarica. - 2015.- 66(4).- pp. 464-467. DOI: 10.1556/018.66.2015.4.11

20. Vladimirov V. A new alien species of Euphorbia (Euphorbiaceae) to the Bulgarian flora / V. Vladimirov, A. S. Petrova // Phytologia Balcanica. - 2009.- 15 (3).- pp. 343-345.

21. Yena A. V. Euphorbia davidii Subils. Med-Checklist Notulae, 30 / A. V. Yena // Willdenowia. - 2011.- Vol. 41, № 4.- P. 317.

22. Zoltán Barina. Current distribution and spreading of Euphorbia davidii (E. dentata agg.) in Europe / Zoltán Barina, Myroslav Shevera, Culiţă Sîrbu, Gyula Pinke // Cent. Eur. J. Biol. - 2013.- T. 8(1). - P. 87-95.

\section{О. Ю. Бондаренко, С. Л. Миронов}

Одеський національний університет імені I. I. Мечникова, кафедра ботаніки,

вул. Дворянська, 2, Одеса, 65082, Україна

\section{EUPHORBIA DAVIDII SUBILS (EUPHORBIACEAE) У ФЛОРI ЗАЛІЗНИЧНИХ КОЛІЙ ДНІСТРОВСЬКОГО ПЕРЕСИПУ}

\section{Резюме}

Мета. Антропогенно перетворені екотопи є осередком для існування багатьох адвентивних видів. Поширення північноамериканського виду Euphorbia davidii підроду Poinsettia на різних континентах часто пов'язують із експортом зерна. Певний час науковці піднімали питання ідентифікації рослин $E$. davidii на нових територіях, оскільки цей вид морфологічно подібний до E. dentata agg.

Вид E. davidii характеризується високим інвазійним потенціалом, є кенофітом. На території України вид представлений окремими локалітетами практично на всій території. Пов’язаний із територіями портів, залізничних колій, необроблюваних земель.

Методи. У 2021 році, маршрутним методом, на ділянках залізничних колій Дністровського пересипу, між з/станціями Кароліна-Бугаз та Сонячна (загаль- 
ною довжиною - до восьми кілометрів), виявлено сім локалітетів E. davidii; в публікації наведено їх координати. Обстежені екотопи характеризуються щебенистим субстратом, з підвищеними температурами, а також специфічним вібраційним, інсоляційним та гідрологічним режимами.

Результати. Представлені як малочисленні локалітети (32 види), так і ділянки, де концентрація рослин становить понад 2000. Протяжність місцезростань від двох метрів до двадцяти. Висота окремих, найбільш розвинених особин, становила $20 \mathrm{~cm}$.

Рослин у міжколійному просторі, як правило - суттєво менше, проте вони краще розвинені, добре галузяться, мають більшу кількість суцвіть 3 плодами.

Висновки. Кількість рослин із південної сторони відкосів колій, як правило більша, проте екземпляри на південних відкосах (порівняно із північними) гірше розвиненні, менше галузяться та, станом на час проведення досліджень, були представлені меншою кількістю генеративних особин. На прилеглих до залізничних колій піщаних ділянках пересипу, рослини E. davidii практично не фіксовані. Знайдені нечисленні екземпляри мали пригнічений ріст, єдине стебло, практично не квітувати та не мали насіння.

Ключові слова: Euphorbia davidii; залізничні колії; Дністровський пересип

\title{
O. Yu. Bondarenko, S. L. Myronov
}

Odesa National Mechnykov University, Faculty of Biology,

Department of Botany

2 Dvorianska str., Odesa 65082, Ukraine

\section{EUPHORIA DAVIDII SUBILS (EUPHORBIACEAE) IN FLORA OF RAILWAY TRACKS OF THE DNIESTER BAY BAR}

\begin{abstract}
Aim. Anthropogenically transformed ecotopes act as a centre for existance of many adventive species. The distribution of North-American species Euphorbia davidii subsp. Poinsettia across various continents is often attributed to the export of grain. For some time scientists have been bringing up the issue about identification of plants $E$. davidii in new territories, because the species is morphologically similar to $E$. dentata agg.

The species $E$. davidii is characterised by a high invasive potential, it is a neophyte. In Ukraine the species is represented by separate localities almost throughout the country. It is related to sectors of ports, railway tracks, and abandoned lands.

Methods. In the year 2021, by means of route method, in sectors of railway tracks of the Dniester bay bar, between the railway stops Karolina-Buhas and Soniachna (total length is up to eight kilometers) seven localities of $E$. davidii were distinguished; the coordinates of the locations are listed in the publication. The examined ecotopes are characterised by a crushed stone substratum, with higher temperatures, and also by specific vibrational, insolational and hydrological modes.
\end{abstract}


Results. Both inconsiderable in number of plants localities (32 exemplars) and zones, where the number of plants reaches over 2000 are represented. The extent of habitats ranges from 2 to 20 meters. The height of particular, the most developed individuals constituted $20 \mathrm{~cm}$. As a rule, in the inter-rail space there is a considerably smaller number of plants, however, they are better developed, well-branched and have more inflorescences with fruits.

Conclusions. A number of plants from the southern slopes of the railways is typically bigger, however, the plants on the southern slopes (in comparison with the northern ones) are worse developed, branch out less and, at the time of conducting the research were represented by a smaller number of generative individuals. In sandy sectors of the bay bar adjoining the railway tracks the plants $E$. davidii were almost not noticed. The individuals found in the above-mentioned sectors are characterised by stunted growth, a single stem, almost did not bloom, and did not produce seeds.

Key words: Euphorbia davidii; railway tracks; the Dniester bay bar

\section{References}

1. Bondarenko O. Yu. (2009). «A summary of the flora of lower Dniester - Tiligul interfluve» [«Konspect flory ponyzzja mezhirichcha Dnister-Tiligul»].- Kyiv: Fitosotsiotsentr, 332 p.

2. Bondarenko O. Yu. (2015). «Flora of lower Dniester-Tiligul interfluve»: $\mathrm{PhD}$ thesis.- Kyiv, $380 \mathrm{p}$.

3. Vasylyeva, T.V. (2003). "A checklist of the flora South Bessarabia" ["Konspect flory Pivdennoi Besarabii"]. I. I. Mechnikov Odesa National University, Odesa: 1-250.

4. Geltman D. V. New localities of the quarantine weed Euphorbia dentata Michx. in Ukraine [Amerikanskii vid Euphorbia davidii Subils (Euphorbiaceae) vo flore Vostochnoi Evropy I Severnogo Kavkaza] // Turczaninowia 2012.- 15 (1): 37-39.

5. Guzik Ya., Protopopova V.V., Kagalo O. O., Moyseenko I. I., Prots B. G., Shevera M. V. (1997). New localities of the quarantine weed Euphorbia dentata Michx. in Ukraine [Novi localitety karantynnogo buryanu Euphorbia dentata Michx. v Ukraini] // Ukr. Botan. zhurn.- 54 (3): 280-283.

6. Dvirna T. S., Zvyagintseva K. O. (2013). Findings of Euphorbia davidii Subils (Euphorbiaceae) in the territory of forest steppe of Left-bank Ukraine [Znakhidky Euphorbia davidii Subils (Euphorbiaceae) na terytorii Livoberezhnogo Lisostepu Urkainy] // Ukr. Botan. zhurn. 70(3): 351-353.

7. Didukh Ya. P., Shelyag-Sosonko Yu. R. (2003). «Geobotanical, zoning of Ukraine and adjusting territories» [Geobotanichne raionuvannia Ukrainy ta sumizhnykh oblastei]. Ukr. botan. zhurn. 60 (1): 6-17.

8. "Invasive species in the flora of the Northern Black Sea coast" [Invasiini vydy u flori Pvnichnogo Prychornomorya] (2009) / [В. В. Протопопова, М.В.Шевера, С. Л. Мосякін та ін.].- Kуiv: Fitosotsiosentr, 56 p.

9. Kovalenko S.G., Petrik S. P., Ruzhitskaya I. P., Vasylyeva-Nemertsalova T. V. (1993). New species of synanthropic flora in Odesa and Black Sea ports [Novi vydy synantropnoi flory $\mathrm{m}$. Odesy ta prychornomorskikh portiv] // Ukr. Botan. zhurn. 50 (1): 114-117.

10. Kovalenko S. G., Ruzhitskaya I.P., Petrik S. P. (1992). New findings of Euphorbia dentata in Black Sea coastal area [Novye nahodki Euphorbia dentata v Prichernomore] // Biull. Glav. bot. sada. Vyp. 163: 62.

11. Protopopova V. V. (1991). Synanthropic flora of Ukrainia and ways of its development.- Kyiv.: Nauk. dumka, $192 \mathrm{p}$.

12. Protopopova V. V., Schevera M.V. (2019). Invasive species in the flora of Ukrainia. I. Group of highly active species [Invasiini vydy u flori Ukrainy. I. Grypa vysokoaktyvnych vydiv] // GEO\&BIO. 17: 116-135.

13. Tohtap V. K., Kurskoi A. Iu. (2019). Euphorbia davidii Subils (Euphorbiaceae) - a new species for Central Black Earth Region (Russia) [Euphorbia davidii Subils (Euphorbiaceae) - novyi vid dlia Centralnogo Chernozemia (Rossia)] // Fitoraznoobrazie Vostochnoi Evropy. XIII (4): 397-401. doi: 10.24411/2072-8816-201910058

14. Burda R. I. Tokhtar V.K. (1992). Invasion, distribution and naturalization of plants along railroads of the Ukrainian south-east // Ukr. Botan. zhurn. 49 (5): 14-18. 
15. Marchessi J.E., Subilis R., Scaramuzzino R. L., Crosta H. N., Eseiza M. F., Saint Andre H. M., Juan V. F. (2011) Presencia de Euphorbia davidii Subils (Euphorbiaceae) en la Provincia de Buenos Aires: morfología y anatomía de la especie. Kurtziana. 36 (1): 45-53.

16. Oprea A., Barina Z., Sîrbu C. (2012). Euphorbia davidii Subilis (Euphorbiaceae) - an alien species new to the Romanian flora. Contribuţii Botanice. 48: 7-12.

17. Pinke G., Molnar S., Garamvölgyi V., Barina Z. (2012). The first occurrence of Euphorbia davidii in Hungary. Nöwenyvedelem. 48 (3): 117-120.

18. Purger D., Vajgand D., Mićić N., Vajgand K. (2015). Euphorbia davidii Subils (Euphorbiaceae), a new alien species in the flora of Serbia. Botanica Serbica. 39 (1): 49-52.

19. Rédei Dóra. (2015). First phytochemical investigation of secondary metabolites of Euphorbia davidii Subils and antiproliferative activity of its extracts / Dóra Rédei, Norbert Kúsz, Máté Szabó, Gyula Pinke, István Zupkó, Judit Hohmann1 // Acta Biologica Hungarica. 66(4): 464-467. DOI: 10.1556/018.66.2015.4.11

20. Vladimirov V., Petrova A. S. (2009). A new alien species of Euphorbia (Euphorbiaceae) to the Bulgarian flora. Phytologia Balcanica. 15 (3): 343-345.

21. Yena A. V. (2011)/ Euphorbia davidii Subils. Med-Checklist Notulae, 30 // Willdenowia. 41 (4): 317.

22. Zoltán Barina, Myroslav Shevera, Culiţă Sîrbu, Gyula Pinke (2012). Current distribution and spreading of Euphorbia davidii (E. dentata agg.) in Europe // Cent. Eur. J. Biol. 8(1): 87-95. 